\title{
Vedic Ritualism and Advaita Vedānta Monastic Institutions in Kerala
}

\author{
Olga Nowicka \\ Institute of Oriental Studies \\ Jagiellonian University
}

\begin{abstract}
According to Kerala legends, around the $9^{\text {th }}$ century, direct disciples of the philosopher Śankara established four Advaita Vedānta Mațhas in Trichur in Kerala, thereafter appointing Nambudiri Samnyāsins as heads of these religious institutions. What is peculiar about these monasteries is the prescription according to which Trichur Mațas were, and still are, intended only for Nambudiri Brahmins, and moreover only for Nambudiris from specific families who keep the Vedic sacrificial tradition. However, the Advaita Vedānta doctrine was not a current concept among Nambudiri Brahmins. Presumably, in the medieval period it was the mīmāṃsā schools of Bhātța and Prābhākara which were favoured among Nambudiris. Nevertheless, the appropriation of the Sankaric model of monasticism somehow seemed to be an alluring modus operandi for the aristocracy of the Nambudiri community to gain considerable power.
\end{abstract}

Key words: Vedic sacrificial tradition, śrauta ritual, agnicayana, Kerala, Nambudiri Brahmins, Vedic altars, fire ritual, Śankkara, Advaita Vedānta monastic institutions, Trichur

Słowa kluczowe: wedyjski rytuał ofiarniczy, rytuał śrauta, agnićajana, Kerala, bramini Nambudiri, ołtarze ofiarnicze, rytuał ogniowy, Śankara, monastycyzm paradygmatu Śankary, Adwaita Wedanta, instytucje monastyczne, Trichur

According to the local hagiographic tradition, around the $9^{\text {th }}$ century, direct disciples of Ādi Śankkara established four Advaita Vedānta Mațhas in Trichur in Kerala (South India), thereafter appointing Nambudiri samnyāsins as heads of these religious institutions. ${ }^{1}$ They were Vadakke Maṭam (from Malayalam: Northern Mața), Thekke Mațham (Southern Mațha), Naduvil Mațham (Middle Mațha), and Edayil Maṭham (Matham Located In-between). ${ }^{2}$ Nowadays, two of the mathas - Naduvil and Thekke

\footnotetext{
1 Preceptors of Advaita, T.M.P. Mahadevan (ed.), Secunderabad 1968, p. 378.

2 A.S. Menon, A Survey of Kerala History, Kottayam 1970, p. 146.
} 
- are still active religious institutions. The third, Vadakke Mațham, was transformed around 400 years ago into a Vedapāțhaśālā (an institution where Vedas are taught), widely known as Vadakke Madham Brahmaswam. As claimed by the Nambudiris in charge of that school, the then Swamiyar (i.e. the pontiff) did not nominate his successor. $^{3}$ The issue of the fourth matha is particularly interesting because this matha is missing. Although the local accounts say that originally four mațas were established, nowadays only three survive in Trichur. Some Nambudiris claim that the fourth one was relocated outside the city. ${ }^{4}$

What is peculiar about these monastic centres is the prescription according to which Trichur mațas were, and still are, not open to any Brahmins at all, but intended only for Nambudiri Brahmins, and moreover only for Nambudiris from specific families who keep the Vedic sacrificial tradition. ${ }^{5}$ Throughout the course of history, in the most prosperous times, the Trichur mathas have been significant institutions, managing many wealthy temples and possessing paddy fields across the whole Malabar region.

The group of four Advaita Vedānta mathas in Trichur remains largely unstudied. In my research I attempt to take an integrative look at the history of those four monastic institutions by tracing the process of incorporating the Advaita Vedānta doctrine into the Nambudiri ideology through appropriation of the Śankara legend in service of the interest of this particular community. As my study on this local tradition is still an ongoing project, in this article I would like to share a few preliminary results obtained to date.

What seems striking about the issue of the four Advaita Vedānta monastic institutions in Trichur is the fact that the legend persistently repeated forcibly obscured the history. We can hardly find out what actually happened due to the lack of veritable historic data. Even the date of the establishment of these institutions, estimated at the $9^{\text {th }}$ century, is legendary.

The only available records referring to the origin of Trichur mathas derive from the Keralan regional hagiographic tradition. According to one of the accounts of the philosopher's life that are popular locally, after coming back from Kāñcī, Śankkara himself established four Advaita Vedānta mațhas in Trichur. Subsequently, he was said to have entrusted their headship respectively to his four main disciples. Hereby the first Swamiyar of the Vadakke Matham was considered to be Totaka, of the Naduvil Mațham - Sureśvara, of the Thekke Mațham - Padmapāda and of the Edayil Matham - Hastāmalaka. ${ }^{6}$ According to another version, it was Śañkara's disciples who after ācārya's samādhi in the Śaiva Vadakkunathan Temple established the aforementioned mathas. Nevertheless, in both variants of the story, Śankara's disciples thereafter appointed Nambudiri samnnyāsins as their successors. ${ }^{7}$

${ }^{3}$ Brahmaswam Madham. The Traditional Vedic Institution, http://brahmaswammadham.blogspot. com/p/history.html [accessed: 18 January 2016].

${ }^{4}$ Swami Anantanandendra Sarasvati, Śri Śankara and Śankarite Institutions [in:] Preceptors of Advaita, T.M.P. Mahadevan (ed.), Secunderabad 1968, p. 378.

5 G.L. Bayi, Thulasi garland, Mumbai 1998, p. 128.

${ }^{6}$ A.S. Menon, A Survey..., p. 146.

${ }^{7}$ Swami Anantanandendra Sarasvati, op. cit., p. 378. 
Apparently this particular account of the philosopher's life must have been popular in Kerala, since to authenticate the course of events in question in the complex of the Vadakkunnathan Temple there is an erected stone platform commemorating Śankara's videha-mukti. Interestingly, the undated platform bears two Vaiṣnava attributes: śankha and cakra. ${ }^{8}$

It seems probable that the local Śankara hagiographic tradition in Kerala could primarily provide an elucidation for the origin of the Advaita Vedānta mathas in Trichur, and also that it determines the community in charge of them. Perhaps it was through an appropriation of Śankkara's legend and an incorporation of the Advaita Vedānta doctrine into Nambudiri ideology that the Trichur mațas became influential institutions wielding religious and political power in medieval Kerala.

It is noteworthy that the Advaita Vedānta doctrine was not a current concept among Nambudiri Brahmins. ${ }^{9}$ The nature of the power-structure created by them was a sort of network woven with interconnections based on the idea of an exclusive ritualism. In fact, the Brahmanic chronicle Keralolpatti depicts Kerala as a karmabhūmi, certainly not without an intended purpose. ${ }^{10}$ Presumably, in the medieval period it was the Mīmāmsā schools of Bhātța and Prābhākara which were favoured among Nambudiris. ${ }^{11}$ The study of Mīmāmsā was said to have been more prominent than that of Vedānta. It is considered that of the eighteen academies of ancient Kerala, six were meant for Prābhākara Mīmāṃsā and six for Bhāț̣a Mīmāṃsā, three for Vedānta, and the remaining three for Vyākaraṇa. Supposedly, in the city of Calicut (North Kerala), under the auspices of Zamorin twelve bags of money were donated to scholars of each Mīmāṃsā school every year. ${ }^{12}$

However, the appropriation of the Śankaric model of monasticism somehow seemed to be an alluring modus operandi for the aristocracy of the Nambudiri community to gain considerable power. Trichur mathas were deriving numerous benefits, including royal land donations, grants, privileges and ordinances, which enabled the other affiliated mathas to be established. ${ }^{13}$ They created a network of complex social, economic and political interrelations. Thereby Trichur institutions possessed paddy fields all over Kerala in the past, managing (which some of them actually still do) a number of temples in the Malabar region. This is proven by the numerous judgments of several courts (e.g. Madras High Court, Kerala State Court). ${ }^{14}$ These

${ }^{8}$ K.R. Vaidyanathan, Temples and Legends of Kerala, Bombay 1982, p. 147.

9 V.G. Namboodiri, Śrauta Sacrifices in Kerala, Calicut 2002, p. 66.

10 "God makes no distinction among the castes. In other regions, there is no pollution or purification for non-touch approaches. But in this holy land where ritual is important, the land is purified by proper observances and ritual action. In lands where true knowledge prevails, all people can live and be together. In the Karma Bhumi, salvation can be obtained only through proper action; so all these have been ordained. [...] And thus it was decided at the great assembly of the 64 villages, by Sankaracharya, the kings, and many holy persons, and the people generally." H. Gundert, Keralolpatti, transl. T.M. Menon, Thiruvananthapuram 2003, p. 63.

${ }^{11}$ V.G. Namboodiri, op. cit., p. 74.

${ }^{12}$ Ibidem, p. 74, 81.

${ }^{13}$ C. Galewicz, Żyjące biblioteki Indii: Rygweda braminów Nambudiri, Kraków 2015, p. 78.

${ }^{14}$ Courts judgments for the years 1916-1961 obtained from http://indiankanoon.org/ [accessed: 18 January 2016]. 
confirm Swamiyar's litigations and claims for such proprieties as lands, temples and their incomes, as well as documenting the royal donations and the issues of headship over particular temples' Devaswams. ${ }^{15}$

The sovereign pontiffs of Trichur mathas wielded objective power in terms of religion as well as politics. Kings frequently sought Swamiyars' advice and endorsement. For instance, Swamiyars of Naduvil Mațham are by heirdom associated with the Padmanabhaswamy Temple in Trivandrum, as confirmed by the Travancore royal family. Naduvil Swamiyars preside over the Ettara Yoga (from Malayalam: Council of Eight and a King) - a body of temple Trustees. The pontiff's statements were of such reverence that at one time the royal family could not even adopt a child without the Naduvil Swamiyar's consent. ${ }^{16}$

In the medieval period, the kings of Venad also lavished much money and attention on the upkeep and functioning of the particular branch of Naduvil Matham called Muñchira Mațham in Mithranandapuram. The reason for this was the fact that one of the mathas' secondary activities appeared to be the maintaining of the Nambudiri Vedic ritualists. It is said that Mithranandapuram was the arena of many Vedic rituals in medieval times, gaining it the stature of Yajña Bhūmi in the distant past. ${ }^{17}$

Another significant relation was certainly the link between the Nambudiri mathas and one of the wealthiest Keralan temples, the Vadakkunnathan Temple in Trichur. We know that besides the legend connecting these two institutions, ceremonial and economic relations have also existed between them. For instance, Thekke Maṭa pontiffs are the Puşpāñjali Swamiyars at the Vadakkunnathan Temple. ${ }^{18}$ Moreover, the Yogiatirippads, that is the ecclesiastical heads of the Vadakkunnathan Temple, were the Nambudiris from specific, influential families, usually from Trichur yogam (yogam - the social organisations affiliating particular Nambudiri families) or Perumanam, who were known for keeping the ancestral Vedic sacrificial tradition; and who exercised jurisdiction over a large portion of what constitutes today's Trichur Taluk. The Yogiatirippads were elected for life by the Nambudiri illams of Trichur and its suburbs. The ceremony of their consecration used to take place in the presence of the Raja of Cochin, local chieftains and prominent Nambudiris from places outside of Trichur. They were, according to Sreedhara Menon, powerful and influential dignitaries. ${ }^{19}$ For instance, under their headship, the Nambudiri families of Trichur and Perumanam were playing active roles in the politics, as when they stood against the ruler of Cochin - Raja Rama Varma, popularly known as Saktan Tampuran (reigned $1790-1805)$ - in his wars with the Zamorin of Calicut. ${ }^{20}$

Therefore, it seems that for Nambudiri yogas such institutions as mathas and temples' boards could also function as specific means of gaining considerable control

15 Devaswom - god's property (i.e. the socio-religious trusts managing the temples in Kerala).

16 G.L. Bayi, Thulasi garland, p. 121.

17 Ibidem.

18 A.S. Menon, Kerala District Gazetteers. Trichur, Thiruvalla 1962, p. 176.

19 Ibidem.

${ }^{20}$ Ibidem. 
over the centres of power, which in medieval Kerala were the kingdoms of Cochin, Calicut and Travancore.

Interestingly enough, the four mațhas in question were established in one city. What is more, they were built next to each other. Further, they were located just a few hundred metres away from the Vadakkunnathan Temple. Thus, the physical space of Trichur was rearranged in order to actualise the ideological concept which gave it a symbolic meaning. The legendary map of Śankara's life became recreated and inscribed in the geographical location of Trichur. But the question is why in this particular city? What we know is that in medieval Kerala Trichur was an important centre associated with one of the two rival institutions, already mentioned before, called yogas. Two of them - Trichur yogam and Tirunāvāya yogam - were associated with two rival kingdoms of medieval Kerala - Calicut and Cochin. ${ }^{21}$ Although little is known about those institutions, it is clear that they were supported by the rulers who were their patrons. Probably these two Nambudiri yogas were also able to compete for the primacy of the peculiar ritualistic techniques (typical of the specific family association) applied during the performance of śrauta rituals. ${ }^{22}$

Therefore, what seems to be of crucial importance is the peculiar prescription according to which those mathas were, and still are, not open to any Brahmins at all, but intended only for Nambudiri Brahmins. Furthermore, to make these institutions even less accessible, additional tightening took effect - only Nambudiris from specific families who practised the Vedic sacrificial tradition could accept samnyāsa there. In fact, out of thirty-two Nambudiri grāmas of Kerala, only six, namely Periñcellūr, Covvaram, Iriññālakkuṭa, Perumanam, Karikkāṭ and Ālattiyūr, are said to have been allowed to preserve the tradition of performing śrauta fire rituals. ${ }^{23}$ Hence, members of those six villages constitute the highly privileged intellectual elite of the subdivided Nambudiri community.

By tradition in the Nambudiri community, only the eldest son in the family could get married to the antarjanam (Skr. antar-jana "person [confined to] indoors" - title of a Nambudiri women), while the younger son should preferably undertake the path of renunciation and accept the samnnyāsa. ${ }^{24}$ It was customary that while the elder brother's role was that of grhastha, the younger brothers were supposed to learn and subsequently teach Vedas, so as to perpetuate the Vaidika tradition. This way of conduct, specific to Nambudiris, has its source in the normative text called Śankarasmrti popular in Kerala, which is supposed to regulate the social and moral life of the Nambudiri Brahmins. In fact, this work, dated approximately to the $14^{\text {th }} / 15^{\text {th }}$ century, assumed much importance as the class of Nambudiri Brahmins had greatly

${ }^{21}$ C. Galewicz, Żyjące biblioteki..., p. 32.

22 Ibidem.

${ }^{23}$ V.G. Namboodiri, op. cit., p. 57.

${ }^{24}$ Skr. jyesțthabhrātā gṛhi bhavet - "[only] the eldest brother shall become a householder" (Śankkarasmrti $1,12,4,24)$. "The position of the younger brothers, said to be worse than that of dogs, could be alleviated in a number of ways even in earlier times. First, they could get respect and income by being teachers of the Vedas and performers of rituals, heads of monasteries, or tantris." M. Parpola, Kerala Brahmins in Transition. A Study of a Nampūtiri Family, Helsinki 2000, p. 152. 
dominated and controlled the social life of Kerala for centuries. The customs exposed in Sankarasmrti are peculiar to Nambudiris, and relatively unknown to other Brahmins. ${ }^{25}$

As regards Naduvil Matha itself, it proves to be customary that only Nambudiris from Śukapuram, Peruvanam and Iriññālakkuṭa grāma having Bhațtavṛ̣tti (lands given on service tenure by the king to Bhațta - usually a mīmāṃsā or vyākaraṇa teacher with high social status ${ }^{26}$ ) and the right to perform agnihotra could accept samnyāsa there. ${ }^{27}$ It is possible that a similar restriction also concerned the remaining Śankaric institutions in Kerala. The enumerated grāmas, as mentioned earlier, belong to lineages who are said to keep Vedic sacrificial tradition. It therefore seems that access to Trichur mathas was restricted only to the most privileged members of the Nambudiri community - the Nambudiri aristocracy, who had the privilege of practising Vedic śrauta rituals.

Ipso facto, the grounds of the exceptional practice of the resident samnyāsins seem to become somewhat clearer. That is to say, it appears that the ascetics from the Trichur Advaita Vedānta mațhas used to take an active interest in the Vedic śrauta sacrificial tradition. ${ }^{28}$ It is known that they contributed several Sanskrit works concerning the Vedic ritualistic practice. Commentaries composed by these ascetics were often focused on the technical details of the Vedic sacrifice. One such samnnyāsins who was the author of the several Sanskrit commentaries to ritual sūtras was known as Yogiyār. He was probably a member of Taikkāt Mana of Covvaram grāma. His actual name was Nilakanthan Nambudiri, and he probably lived around the $16^{\text {th }}$ century. His major work is considered to be Kārikās of Yogiyār. These Sanskrit verses were the manual for the construction of yāgaśâlā and the details of building the fire altars during the Agnicayana ritual. The text describes three kinds of altar shapes specific to Keralan sacrificial tradition. ${ }^{29}$ These are: the square falcon, called Vaidikans pitthan, the falcon with five set of nails, called pañcapatrika, and one with six sets of nails, called șatpatrika. They are considered to represent three stages of life - the first shape symbolises the nestling (Skr. bāla), the second one represents the young bird (Skr. yuvan), and the third symbolises the grown-up bird (Skr. vrddha).$^{30}$ The text explains the construction details of those three most common forms of fire altars practised in Kerala. According to Prof. Nilakanthan from the Sree Śankara University in Kalady, the Kārikās of Yogiyār are the only known independent work in Sanskrit from the post-Śulvasūtra period, which deals with fire altar constructions. ${ }^{31}$

For the time being, we know of two other Sanskrit texts written by Yogiyār; one of them is entitled Śrauta-prāyaścitta-samgraha, and is composed of ten chapters. The

\footnotetext{
${ }^{25}$ Ibidem, pp. 40-44.

${ }^{26}$ K. Veluthat, Brahman Settlements in Kerala. Historical Studies, Thrissur 2013, p. 156.

${ }^{27}$ G.L. Bayi, Thulasi garland, p. 128.

28 V.G. Namboodiri, op. cit., p. 74.

29 D.S. Sivanandan, New Found Hitherto Unknown Malayalam Text on Agni-New Insights on the Śulbasūtra Tradition in Kerala, "Bulletin of Kerala Mathematics Association" 2010, vol. 6, no. 1, p. 61.

${ }^{30}$ Yogiyāruțe Kārikā, manuscript copy obtained from Taikkāṭ Mana, Edappal, Kerala, India.

${ }^{31}$ D.S. Sivanandan, New Found..., p. 61.
} 
text deals with the prāyaścitta ${ }^{32}$ rules for the Vedic ritualists who happen to make a mistake in the ritual procedure. Another of his works was Sägnikam-atirātramanukraman̄i . It consists of 307 verses and concerns the course of action during the Atirātra śrauta ritual..$^{33}$

As one can observe, all the mentioned texts were ritualistic works exposing the intricacies of the Keralan Vedic sacrificial tradition, very technical in nature, which clearly points to the author's origin - the Nambudiri Vaidika family.

Moreover, in the course of history, Swamiyars from Trichur mathas at times also oversaw the performance of the Vedic śrauta rituals to some degree. For instance, Kaliyatt Swamiyar of Trichur was present at Taikkāt Mana for giving advice when the Ŗtviks were given training for Kundur Atirātra in $1990 .{ }^{34}$ In 2012, meanwhile, Swamiyar Shankarananda Brahmanandabhoothi from Thekke Mațham was keeping an eye on the ritual performance during Atirātra held in Kodakara. ${ }^{35}$

To summarise, by creating a peculiar complex power structure it seems that Nambudiris have dominated the Keralan society and gained the most direct political control. In particular Swamiyars from the Advaita Vedānta mathas and the ecclesiastical heads of the Vadakkunnathan Temple board, parts of Trichur dominated which in medieval times had the densest Nambudiri concentration. ${ }^{36}$ In other cases, as Joan Mencher noticed, Nambudiris could make use of indirect power and put various kind of pressure on the rulers as the highest spiritual authorities in the region. ${ }^{37}$ Mencher claims that they could also act as messengers and communicators in the entire land of Kerala, thereby securing preservation of the complex system. ${ }^{38}$ The final result of an extensive process of structural transformation was therefore the domination of the religious system based on the Vedic sacrificial tradition's preeminence. ${ }^{39}$ Though seemingly contradictory to the karmakāṇạa conduct, the adopted Śankaric model of monasticism somehow appeared to be an effective modus operandi for the aristocracy of the Nambudiri community to gain considerable power. It did not, however, prevent the adherence to the purely ritualistic practice of the śrauta ritual, which was a determinant of the highest social status; it rather led towards a more syncretistic approach.

It therefore seems that, by appropriating Śankara's legend and incorporating the Advaita Vedānta doctrine into Nambudiri ideology, Trichur mațhas became influential institutions wielding religious and political power in medieval Kerala.

${ }^{32}$ Skr. prāyaścitta - "atonement," "expiation," "amends."

33 V.G. Namboodiri, op. cit., p. 84.

${ }^{34}$ Ibidem, p. 74.

35 “Athirathram enters second half," The Hindu, 29 March 2012, http://www.thehindu.com/todayspaper/tp-national/tp-kerala/athirathram-enters-second-half/article3256737.ece [accessed: 18 January 2016].

36 J. Mencher, Namboodiri Brahmans: An Analysis of a Traditional Elite in Kerala, "Journal of Asian and African Studies" 1966, no.1, pp. 186-187.

37 Ibidem.

${ }^{38}$ Ibidem.

${ }^{39}$ M. Parpola, op. cit., p. 18. 


\section{Bibliography}

Achyuthan A., Prabhu T.S. Balagopal, An Architectural Guide of Thrissur, Calicut 1996.

Aiya Nagam V., The Travancore State Manual, vol. 2, New Delhi 1989.

Aiyer Nataraja A., Sastri S.L., The Traditional Age of Sri Sankaracharya and the Maths, Madras 1962.

Antarkar W.R., Śankara-Vijayas. A Comparative and a Critical Study, Mumbai 2003.

Bader J., Conquest of the Four Quarters: Traditional Accounts of the Life of Śankara, New Delhi 2000.

Bayi G.L., Sree Padmanabha Swamy Temple, Mumbai 2013.

Bayi G.L., Thulasi garland, Mumbai 1998.

Brahmaswam Madham. The Traditional Vedic Institution, http://brahmaswammadham.blogspot. com/p/history.html [accessed: 18 January 2016].

Cenkner W., A Tradition of Teachers: Śankara and the Jagadgurus Today, Delhi 1995.

Champakalakshmy R., Veluthat K., Venugopalan T.R., State and Society in Pre-modern South India, Thrissur 2002.

Clark M., The Daśanāmī-Samnyāsīs. The Integration of Ascetic Lineages into an Order, Leiden 2006.

Dubois J., The Hidden Lives of Brahman: Śankkara's Vedānta through His Upaniṣad Commentaries, in Light of Contemporary Practice, Albany 2014.

Farquhar J.N., The Organization of the Sannyāsis of the Vedānta, "Journal of the Royal Asiatic Society of Great Britain and Ireland" 1925, no. 3, pp. 479-486.

Galewicz C., La mémoire et l'oubli. La mémorisation du Rgveda chez les Nambudiri du Kérala [in:] Lieux de Savoir II - Les mains de l'intellect, C. Jacob (ed.), Paris 2011.

Galewicz C., Żyjace biblioteki Indii: Rygweda braminów Nambudiri, Kraków 2015.

Giri S., Society and Sannyāsin. A History of the Daśanāmī Sannyāsins, Rishikesh 1976.

Gonda J., A History of Indian Literature: Veda and Upanishads. The Ritual Sütras, vol. 1, Wiesbaden 1977.

Gundert H., Keralolpatti, transl. T.M. Menon, Thiruvananthapuram 2003.

Krishnamachariar M., History of Classical Sanskrit Literature, Madras 1937.

Mahadevan T.P., Staal F., The Turning Point in a Living Tradition, Somayāgam 2003, "Electronic Journal of Vedic Studies" 2003, vol. 10, pp. 1-25.

Mencher J., Namboodiri Brahmans: An Analysis of a Traditional Elite in Kerala, "Journal of Asian and African Studies" 1966, no. 1, pp. 183-196.

Menon A.S., A Survey of Kerala History, Kottayam 1970.

Menon A.S., Cultural Heritage of Kerala. An Introduction, Cochin 1978.

Menon A.S., Kerala Districts Gazetteers: Trichur, Thiruvalla 1962.

Menon A.S., Social and Cultural History of Kerala, New Delhi 1979.

Milner M., Status and Sacredness. A General Theory of Status Relations and an Analysis of Indian Culture, New York 1994.

Nair Ramachandran K.K.A., Kerala District Gazetteers: Trichur. Supplement, Shoranur 1981.

Namboodiri G.V., Srauta Sacrifices in Kerala, Calicut 2002.

Narayanan M.G.S., Aspects of Aryanisation in Kerala, Trivandrum 1973.

Narayanan M.G.S., Perumals of Kerala. Brahmin Oligarchy and Ritual Monarchy, Thrissur 2013.

Narayanan M.G.S., Re-interpretations in South Indian History, Trivandrum 1977.

Paniker Ayyappa K., A Short History of Malayalam Literature, Thiruvananthapuram 1998.

Parpola M., Kerala Brahmins in Transition. A Study of a Nampūtiri Family, Helsinki 2000.

Pisharothi K.R., The Three Great Philosophers of Kerala [in:] The Indian Historical Quarterly, N. Nath Law (ed.), vol. 5, Calcutta 1929.

Sawai Y., The Faith of Ascetics and Lay Smārtas. A Study of the Śankaran Tradition of Śrngeri, Vienna 1992. 
Sax W.S., Conquering the Quarters: Religion and Politics in Hinduism, "International Journal of Hindu Studies" 2000, vol. 4, no. 1, pp. 39-60.

Sivanandan D.S., New Found Hitherto Unknown Malayalam Text on Agni - New Insights on the Śulbasūtra Tradition in Kerala, "Bulletin of Kerala Mathematics Association" 2010, vol. 6, no. 1, pp. 59-67.

Sivanandan D.S., The Continuity of Śulbasutra Tradition as Evident in the Agnichayana Ritual of Kerala. A Study, paper presented at the International Conference of Sanskrit and Intellectual Heritage, 22-24 February, University of Kerala, Trivandrum 2010.

Staal F., Agni: The Vedic Ritual of the Fire Altar, vol. 1-2, New Delhi 2010.

Sundaresan V., Conflicting Hagiographies and History: The Place of Śankaravijaya Texts in Advaita Tradition, "International Journal of Hindu Studies" 2000, vol. 4, no. 2, pp. 109-184.

Swami Anantanandendra Sarasvati, Śri Śankara and Śankarite Institutions [in:] Preceptors of Advaita, T.M.P. Mahadevan (ed.), Secunderabad 1968, p. 378.

Vaidyanathan K.R., Temples and Legends of Kerala, Bombay 1982.

Veluthat K., Brahman Settlements in Kerala. Historical Studies, Thrissur 2013.

Veluthat K., The Early Medieval in South India, New Delhi 2013.

Veluthat K., The Political Structure of Early Medieval South India, New Delhi 2012.

Wood A., Knowledge Before Printing and After. The Indian Tradition in Changing Kerala, Delhi 1985.

Yogiyāruțe Kārikā, manuscript copy obtained from Taikkāṭ Mana, Edappal, Kerala, India. 